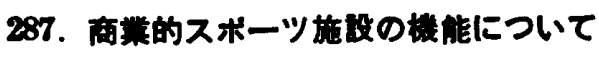

$\begin{array}{ll}\text { 広 島 大 学 } \bigcirc 三 \text { 宅 清香, 三好 喬 } \\ \text { 岡山県立短期大学 } & \text { 神 文 雄 }\end{array}$

\section{I. 研究目的}

発展する福山市の商業的スポーツ施設の実態や問題点 を利用者の側から調べて，その役割の一側面を明らが し，スポーツ活動を進める上での一资料とする.

\section{II. 调查方法}

昭和 42 年 8 月，福山市の $\mathrm{F}$ ブールの一定期間の大人 の入場者を対象に逼定し，質問紙（郵送）面接，文献资 料を用いた。

\section{III. 查結果}

1）調查対象の特質：年代別では男女とる20代の利 用が圧倒的であり，末・既婚者は約半数ずつである. 全 般的に才内の比較的大さな職場に勤める高卒のサラリー マンが多い。

2）スポーツ活動の現状：プール利用者の活動種目 は水泳, 野球, 卓球等比較的限られており, 活動回数は 月 1〜2回である. 商業施設では、プールやボーリング 場を主に利用し，一部の人がゴルフやバッテインク等も 時々行なつている. 施設や用具の琶知については具体的
な商業的施設は伀籍に知つているが，厰場や地域の施設 や用具に関しては，全般的に存在が薄く，無関心な㥞で ある.プールは主に，気分転換や余眼活動の場として利 用されている. 気轾に行け，清潔で安全である等からプ 一ルは好評であるが，他の商業施設については，かなり 批判的である.

\section{IV. 要的}

以上から商業的スポーツ施設は職場や地域の施設や用 具の乏しい現状では，設備が整い，手軽に行けるスポー ッ活動の場として，又，余䂸活動の場として期待される あのである.この钼点から見れば，プールはゴルフやバ ッテインク場等に比べて性や年代に限られることなく手 軽に利用出来るといら特殊性があるにもかかわらず，利 用者は市内の比交的大きな職場のサラリーマンに限られ ている、しかし、利用者にとつて、「よかつた」といら 使用後の感想が多く，このことは注目すべき事柄であ る. 又, 1 日平均 500 人の利用があり, 学生に比べて一 般市民の利用が非常に多く，スポーツ活動の種目や回数 の比茭的少ない人が利用している等の点から、ブールは 一般市民にとつて，余㜊活動の場として，又、スポーツ 活動の場としての役割を果している.

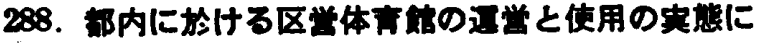 つい}

\section{I. 研究の目的}

東京都立大学○二条 康邦, 影山 健

都市に打ける社会体育の振興にとつて，体育施設の整 備は桑要事となつてきている．しかるに体育施設の整備 基準について，具体的なものは汪とんどないといつても よい，そこで本年度より都立大学において，都市に括け る体育施設基準設定のための基礎的研究を行つてきてい るが.この研究はその一環として都内区立体有館の利用 状況を管理運営面との関係から明らかにし，望ましいあ り方を教えるための其礎资料とすることを目的とした。

II. 方 法

A) 調查対象之数

本年度新設のすのを除き，台東体青館を加えた11を 対象とした。

B) 調查の内容

使用の率・人員・種別・頻度等と管理運営の方法につ いて，その中，使用率を中心に報告する。

C) 調査の方法 面接と申込書の分析

D) 調查期間 昭和 42 年 4 月〜 9 月の半年間

III. 桔

\section{a) 使用対象}

1）スポーツのみに使用…杉並・北区

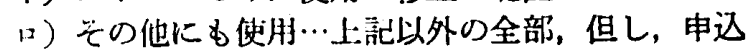
撕日に時差を設けスホーーツ俓先を計つているも
のあある.

b ) スポーツ使用率の高低

使用料金の高低・競技場面䅡の大小等をその要因 の一つと考えられる.

c）借し出しの対象

イ）誰にでも…大田他 4 館

口）区民優先…新宿他 3 館（申込期日に時差を設け ているところあある)

d）スポーツでの使用率

1）練習に多く使用 $\cdots$ 新宿・杉並・北 新宿・北は公開日の多いこと，杉並は使用料が 安いことがその一因と思われる。

口）大会に多く使用…大田・世田谷・台東 3つとす競技場面積が大きく，大田・台東は使 用料子高い。

e ）スポーツ以外の使用率‥大田・足立・台東 大田には分館があり，台東は財団法人である．足 立は管理螘営以外の要因が強いと思われるが，今回 の調查範囲では不明。

IV.

体育館には大会中心型と練凅中心型とがあるが。一般 の人も使用する後者のタイプに问つて行く程こうがあ る. 各体育館で，公開日やスポーツ教室等が開かれ一般 の人の使用率は高まつている. しかし使用料の点で限界 があるようである. また体有館は独自の事業が打ち出せ ない制度の所が多い，一般の利用を打ち出そうこして む,これらの点を是正しない限り限界がある。 